\title{
PDGFA wt Allele
}

National Cancer Institute

\section{Source}

National Cancer Institute. PDGFA wt Allele. NCI Thesaurus. Code C51519.

Human PDGFA wild-type allele is located within 7p22 and is approximately $22 \mathrm{~kb}$ in length.

This allele, which encodes platelet-derived growth factor subunit A protein, plays a role in mitogenesis for mesenchymal cells. 